\title{
Role of DNA Methylation in the Development of Diffuse-Type Gastric Cancer
}

\author{
Eiichiro Yamamoto ${ }^{a, b}$ Hiromu Suzuki ${ }^{a}$ b Hiroyuki Takamaru ${ }^{a}$ \\ Hiroyuki Yamamoto $^{a}$ Minoru Toyota $^{b}$ Yasuhisa Shinomura ${ }^{a}$ \\ ${ }^{a}$ First Department of Internal Medicine and ${ }^{b}$ Department of Biochemistry, Sapporo Medical University, \\ Sapporo, Japan
}

\section{Key Words}

Diffuse-type gastric cancer - Helicobacter pylori •

Epstein-Barr virus $\cdot$ DNA methylation

\begin{abstract}
Cancer cells exhibit two opposing methylation abnormalities: genome-wide hypomethylation and gene promoter hypermethylation. Downregulation of E-cadherin $(\mathrm{CDH} 1)$ plays a key role in the development of diffuse-type gastric cancer, and DNA methylation is a major cause of the gene's silencing. Hereditary diffuse gastric cancer is caused by germline mutation of $\mathrm{CDH} 1$ gene, and DNA methylation frequently serves as the second hit completely inactivating the gene. In sporadic diffuse-type gastric cancer, methylation of $\mathrm{CDH} 1$ is more prevalent than mutation of the gene. Epstein-Barr virus (EBV)-associated gastric carcinoma (EBV-associated GC) is characterized by concurrent methylation of multiple genes, and diffuse-type gastric cancer is frequently seen among EBV-associated GCs. Patients with pangastritis or enlargedfold gastritis, which are both caused by Helicobacter pylori infection, reportedly have an increased risk for diffuse-type gastric cancer. Notably, the gastric mucosa of enlarged-fold gastritis patients exhibits $\mathrm{CDH} 1$ hypermethylation and genome-wide hypomethylation. These data suggest that aber-
\end{abstract}

rant DNA methylation is an essential promoter of carcinogenesis in individuals at high risk for diffuse-type gastric cancer.

Copyright $\odot 2011$ S. Karger AG, Basel

\section{Introduction}

Gastric cancer is one of the most commonly occurring malignant neoplasms, worldwide, and remains a leading cause of cancer death in Asia and some European countries [1]. It is clear that the major etiologic risk factor for gastric cancer is Helicobacter pylori infection [2]; however, only a small proportion of individuals infected with $H$. pylori develop gastric cancer, and it is difficult for physicians to conduct proper early detection and prevention of the disease. Consequently, the development of appropriate biomarkers that reflect an individual's cancer risk is essential to reduce mortality from gastric cancer.

Gastric cancers are divided into two distinct histological groups, intestinal and diffuse [3]. Differences in the clinicopathological characteristics between these two types indicate that they develop via distinct molecular pathways. Intestinal-type cancers are histologically differentiated and are thought to be derived from gastric

\section{KARGER}

Fax +4161306 1234

E-Mail karger@karger.ch

www.karger.com
(C) 2011 S. Karger AG, Basel

0012-2823/11/0834-0241\$38.00/0

Accessible online at:

www.karger.com/dig
Yasuhisa Shinomura, MD, $\mathrm{PhD}$

First Department of Internal Medicine, Sapporo Medical University

S1, W16, Chuo-Ku, Sapporo 064-8543 (Japan)

Tel. +81 11611 2111, Fax +81 116112242

E-Mailshinomura@sapmed.ac.jp 
mucosa cells. It is believed that $H$. pylori infection plays a pivotal role in the development of intestinal-type gastric cancer, which arises from chronic gastritis, atrophy and intestinal metaplasia. Indeed, it is well known that patients with high-grade atrophic gastritis and intestinal metaplasia are at high risk of developing gastric cancer. On the other hand, the sequence of events via which histologically undifferentiated diffuse-type gastric cancers develop is poorly understood, though it is thought that a subset of diffuse-type gastric cancers develop independently of atrophic gastritis or intestinal metaplasia. In contrast to hereditary diffuse gastric cancer (HDGC), $H$. pylori and/or Epstein-Barr virus (EBV) infections reportedly play essential roles in the development of sporadic diffuse-type gastric cancers. In particular, patients with pangastritis and enlarged-fold gastritis, the cause of which is $H$. pylori infection, are reportedly at increased risk of developing diffuse-type gastric cancer $[2,4,5]$.

Cancer is thought to arise through the accumulation of multiple genetic alterations, leading to activation of oncogenes and loss of function of tumor-suppressor genes. With respect to the latter, mutation of $\mathrm{p} 53$ gene is seen in approximately $40 \%$ of intestinal-type gastric cancers, but it is rare in diffuse-type gastric cancers $[6,7]$. $\mathrm{CDH} 1$, which encodes E-cadherin, is frequently mutated in sporadic diffuse-type gastric cancers [8], and germline mutations of CDH1 are detected in a subset of HDGC patients [9]. In addition, activation of Wnt signaling through mutation of APC is a common feature of colorectal cancer, and APC mutation is also frequently seen in gastric adenoma. By contrast, APC mutation is not often seen in either intestinal- and diffuse-type gastric cancers $[6,7$, 10]. With respect to oncogenes, activating mutation of CTNNB1, which encodes $\beta$-catenin, is seen in approximately $20 \%$ of intestinal-type gastric cancers [11], while the frequency of KRAS mutation is low in both histological types [10]. Taken together, these data suggest that, as compared to other cancer types (e.g. colorectal cancers), genetic mutations are relatively infrequent in gastric cancer [12].

A growing body of evidence now suggests that, in addition to genetic alterations, epigenetic changes, including DNA methylation and histone modification, also play important roles in the development and progression of human malignancies [13-16]. Epigenetics are inherited factors that influence gene activity but do not alter primary DNA sequences; among them, DNA methylation is a key event that silences gene expression. It has been hypothesized that DNA methylation initially evolved as a defense mechanism against viruses and other DNA pathogens. Under normal physiological conditions, DNA methylation plays a role in genome imprinting, X-chromosome inactivation and inactivation of repetitive sequences. In cancer, however, two contradicting epigenetic events coexist, namely global hypomethylation, which is mainly observed in repetitive sequences within the genome, and regional hypermethylation, which is frequently associated with $\mathrm{CpG}$ islands in gene promoters. Global hypomethylation is thought to be associated with proto-oncogene activation and chromosomal instability, whereas regional hypermethylation leads to inactivation of tumor-suppressor genes.

A number of studies provide evidence that both genetic and epigenetic alterations play critical roles in gastric tumorigenesis. For example, approximately $20 \%$ of intestinal-type gastric cancers show microsatellite instability that is closely associated with hypermethylation of MLH1 gene [17, 18]. A number of tumor-suppressor and tumor-related genes, including APC, CDH1 (E-cadherin), CHFR, DAPK, GSTP1, p16 and RUNX3, are known to be silenced by hypermethylation in gastric cancer $[15,16,19]$. Moreover, such methylation is frequently observed at premalignant stages of gastric cancer (e.g. with chronic gastritis and intestinal metaplasia), suggesting that aberrant methylation occurs early during the multistep process of gastric carcinogenesis [20-23]. Accumulation of aberrant methylation is thought to promote carcinogenesis through activation of common cancer pathways. For instance, although genetic mutation of APC or CTNNB1 is relatively infrequent in gastric cancer, a number of negative regulators of Wnt signaling, including SFRP1, SFRP2, DKK2, DKK3 and WIF1, are frequently methylated in gastric cancer [24-26]. In addition, methylation of RASSF family genes is thought to serve as an alternative to KRAS mutation in the signaling pathway leading to activation the Ras [27].

Mounting evidence suggests that diffuse-type gastric cancer is strongly associated with aberrant DNA methylation. A subset of cancers that exhibit concurrent hypermethylation of multiple genes is thought to represent a CpG island methylator phenotype (CIMP) [28]. In colorectal cancer, CIMP is strongly associated with MLH1 methylation and microsatellite instability [28]. In gastric cancer, however, CIMP is frequently observed in diffuse-type cancers in which MLH1 methylation and microsatellite instability are less frequent [29]. In this review, we will highlight the contribution made by DNA methylation to the development of diffuse-type gastric cancer, and its clinical application as a potential biomarker. 
Fig. 1. a DNA methyltransferases (DNMTs) catalyze the methylation of cytosine using S-adenosylmethionine (SAM) as the methyl donor. b DNA methylation is maintained after DNA replication by a maintenance DNA methyltransferase, DNMT1.

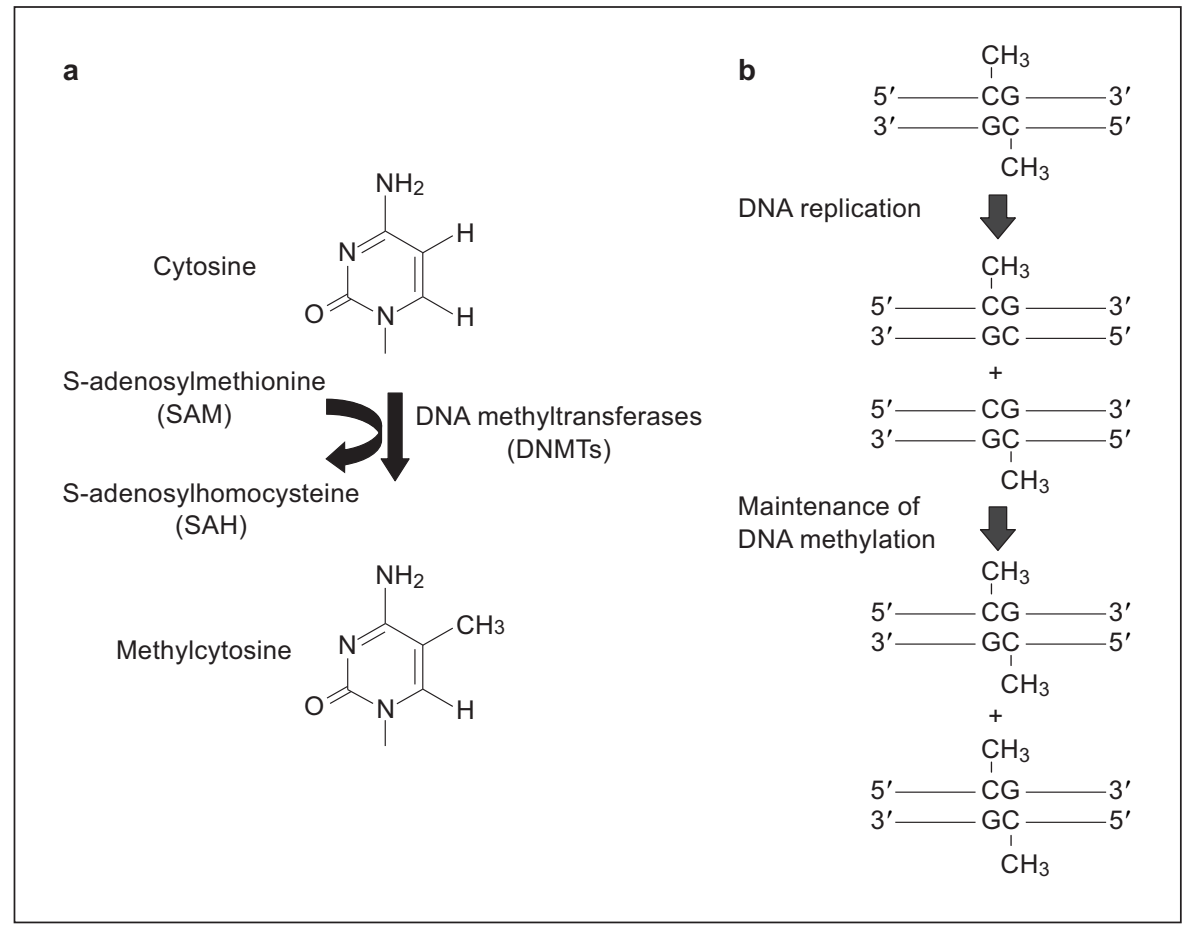

\section{Hereditary Diffuse Gastric Cancer}

According to the International Gastric Cancer Linkage Consortium, HDGC is clinically characterized by either (1) two or more documented cases of diffuse gastric cancer in first- or second-degree relatives with at least one diagnosed before age 50 years, or (2) three or more cases of documented diffuse gastric cancer in first- or seconddegree relatives, independent of the age of onset [30]. HDGC is an autosomal-dominant inherent cancer syndrome, and approximately $30 \%$ of individuals with a clinical diagnosis of HDGC harbor germline mutation of $\mathrm{CDH} 1[31,32]$. Among individuals with $\mathrm{CDH} 1$ germline mutations, the cumulative risk of advanced gastric cancer by age 80 years is $69 \%$ in men and $83 \%$ in women [33].

$\mathrm{CDH} 1$ is located on chromosome 16q22.1 and encodes E-cadherin, which is a transmembrane homodimeric protein that is central to calcium-dependent adhesion of epithelial cells. The mature protein is comprised of three major domains: a large extracellular domain and smaller transmembrane and cytoplasmic domains. The $\mathrm{N}$-terminal ends of the large extracellular domains of the dimers interact with similar E-cadherin dimers on opposing cell surfaces, while the C-terminal ends of the cytoplasmic domains associate with the actin cytoskeleton via a complex that includes $\alpha$-catenin, $\beta$-catenin and $\gamma$-catenin.
And by competing with APC for binding to $\beta$-catenin, E-cadherin also modulates activity in the intracellular $\beta$ catenin signaling pathway [34]. Loss of E-cadherin is believed to lead to loss of cell adhesion, which would promote invasion and metastasis. Among all the reported $\mathrm{CDH} 1$ germline mutations, approximately $80 \%$ are predicted to generate truncated E-cadherin transcripts (nonsense, splice-site and frameshift mutations), while the remaining $20 \%$ are missense mutations [31, 35].

In addition to genetic mutation or allelic loss, epigenetic gene silencing associated with DNA methylation is now recognized as an alternative mechanism by which tumor-suppressor genes are inactivated. Within the mammalian genome, DNA methylation occurs only at cytosine bases located $5^{\prime}$ to a guanosine in a CpG dinucleotide (fig. 1). This dinucleotide is actually underrepresented in much of the genome, but short regions ( $>500 \mathrm{bp}$ in length) known as $\mathrm{CpG}$ islands are rich in $\mathrm{CpG}$ dinucleotides [36]. The majority of $\mathrm{CpG}$ islands are found in the $5^{\prime}$ end regions of approximately half of the genes in the human genome, and are generally unmethylated in normal cells. By contrast, a number of tumor-suppressor and tumor-associated genes are hypermethylated and transcriptionally inactivated in cancer cells (fig. 2). CDH1 promoter methylation and intragenic deletions in the wild-type allele are frequently observed in HDGC and 


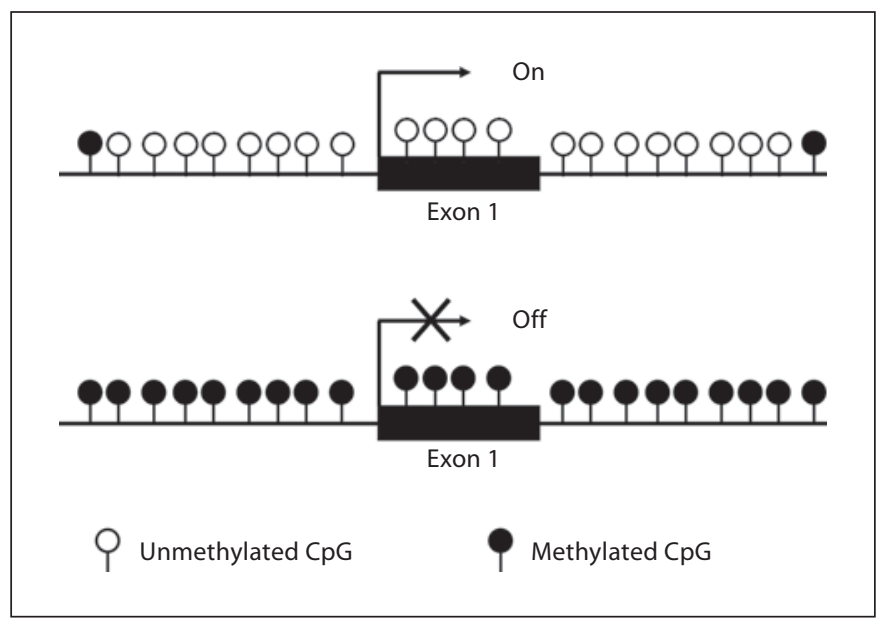

Fig. 2. Methylation of a $\mathrm{CpG}$ island within a gene promoter and transcriptional silencing. a In normal cells, most CpG islands are unmethylated, and gene transcription is active. b In cancer cells, the $\mathrm{CpG}$ islands of a number of genes are hypermethylated, which results in transcriptional silencing of the genes.

are thought to serve as a second hit that completely inactivates the gene $[37,38]$, although the specific mechanisms by which DNA methylation is altered in cancer remain unclear. Recently, the use of endogastric capsules has enabled successful detection of CDH1 methylation in DNA from the gastric juice of diffuse-type gastric cancer patients [39]. Because methylation is one of the major mechanisms involved in the second hit in $\mathrm{CDH} 1$ germline mutation carriers, assessing the methylation of $\mathrm{CDH} 1$ in gastric juice could be a non-invasive way of detecting individuals carrying mutations that put them at greater risk of developing HDGC.

\section{Epstein-Barr Virus-Associated Gastric Carcinoma}

EBV is a ubiquitous human herpes virus that was first identified in Burkitt's lymphoma cells. EBV is transmitted from host to host mainly via saliva, and has been established as a persistent infection of B-cells in over $90 \%$ of the world's adult population [40]. EBV does not usually replicate in B-cells, but instead establishes a latent infection characterized by limited expression of a subset of latent virus genes. Although the vast majority of EBV infections remain asymptomatic throughout one's entire life, a small portion of infected individuals develop tumors, and EBV has been implicated in the oncogenesis of lymphoproliferative diseases such as Burkitt's lymphoma and Hodgkin lymphoma. EBV has also been detected in certain epithelial tumors, including carcinomas of the nasopharynx and stomach.

EBV-associated gastric carcinoma (EBV-associated GC) is defined by the presence of EBV within tumor cells [41-43]. EBV, or its small non-coding RNA (EBER1 and EBER2), has been identified in nearly all neoplastic cells in EBV-associated GC tissue samples. Burke et al. [44] first reported detecting the EBV genome in lymphoepithelioma-like carcinoma, which accounts for approximately $1 \%$ of gastric cancers. Lymphoepitheliomalike carcinomas are almost always EBV-positive, and are characterized as a poorly differentiated carcinoma with dense infiltration of lymphocytes. EBV is also detected in about $5-10 \%$ of ordinary types of gastric cancer. EBVassociated GCs are observed among all types of gastric adenocarcinoma, but they are slightly more common in moderately differentiated tubular types and poorly differentiated solid types. EBV-associated GCs are also more likely in males than females, and are less likely to be found in the gastric antrum than in the cardia or body.

Evidence suggests that epigenetic abnormalities play pivotal roles in the development of EBV-associated GC. Although p53 mutations are found in about $30-40 \%$ of gastric cancers, p53 is mutated in less than $10 \%$ of EBVassociated GCs [42, 43]. In contrast, hypermethylation of tumor-suppressor genes such as CDH1, p14, p15 and p16 is frequently observed in EBV-associated GC [43, 45]. In particular, simultaneous hypermethylation of the promoters of multiple genes (i.e. CIMP) is a characteristic abnormality in EBV-associated GC [29, 46-48]. CIMP was originally defined in the context of gastric cancer using methylation of five CIMP marker loci (MINT1, 2, 12, 25 and 31) identified by Toyota et al. [49]. Tumors showing methylation of 4 or 5 of the markers were defined as CIMP-high (CIMP-H), while those with 1-3 markers were CIMP-low (CIMP-L), and those with no methylation were CIMP-negative (CIMP-N) [29]. To further characterize CIMP in gastric cancer, we assessed the methylation status of 12 other genes (BNIP3, CHFR, CSPG2, p16, HLTF, HRK, PAX5 $\beta$, SLC5A8, p57, MLH1, SOCS-3, TIG1) and compared it with the tumors' CIMP status [29]. We found that $24 \%$ of gastric cancers are CIMP-H, as are all EBV-positive cancers, which accounts for approximately half of the CIMP-H tumors. As compared to the CIMP-L/CIMP-N group, CIMP-H tumors show frequent methylation of the aforementioned 12 genes, and are positively associated 
with upper stomach localization and diffuse-type of histology. And when Chang et al. [47] used five different genes (LOX, HRASLS, FLNc, HAND1 and TM) as CIMP markers and defined CIMP using the same criteria as Toyota et al. [49] - i.e., tumors with $>4$ markers were defined as CIMP- $\mathrm{H}$, those with 1-3 marker were CIMP-intermediate (CIMP-I), and those without methylation were CIMP-N - they too found that $24 \%$ of gastric cancers are CIMP-H, as are nearly all cases of EBVassociated GC.

Interestingly, EBV-negative CIMP-H gastric cancers are strongly associated with MLH1 methylation and microsatellite instability, whereas EBV-positive CIMP-H gastric cancers are strongly associated with diffuse-type of histology and rarely show MLH1 methylation [29, 4648]. It thus appears that EBV-positive and -negative cancers represent distinct subclasses among CIMP-H gastric cancers. Given that DNA methylation is utilized as a host defense mechanism to suppress the expression of viral genes, it is plausible that EBV may activate a methylation pathway that affects multiple genes during gastric carcinogenesis, although the molecular mechanism underlying EBV-associated aberrant methylation is currently unknown.

Synchronous multicentric cancers are frequently reported in EBV-associated GC patients, suggesting that, with EBV infection, the gastric mucosa is at high risk of carcinogenesis. A marked degree of atrophy and a moderate to marked degree of lymphocytic infiltration were observed in the mucosa surrounding EBV-associated GC, but not EBV-negative GC. It is plausible that $H$. pylori infection is associated with the atrophy and inflammation in the gastric mucosa surrounding EBV-associated GC, although it is still controversial whether the rate of $H$. $p y$ lori infection is higher among EBV-positive individuals than among those that are not infected. In situ hybridization analysis revealed that EBERs are rarely expressed in non-neoplastic epithelia adjacent to gastric cancers, but are present in a small portion of infiltrating lymphocytes $[50,51]$. In addition, p14, p16 and p73 are commonly methylated in EBV-associated GC, whereas methylation was less frequently detected in surrounding non-neoplastic mucosa [52]. To date, there have been no studies examining $\mathrm{CDH} 1$ methylation in the gastric mucosa surrounding EBV-associated GC. Further analysis of aberrant DNA methylation in both EBV-associated GC and the adjacent gastric mucosa may lead to identification of new molecular markers for risk prediction and early diagnosis.

Role of DNA Methylation in

Diffuse-Type Gastric Cancer

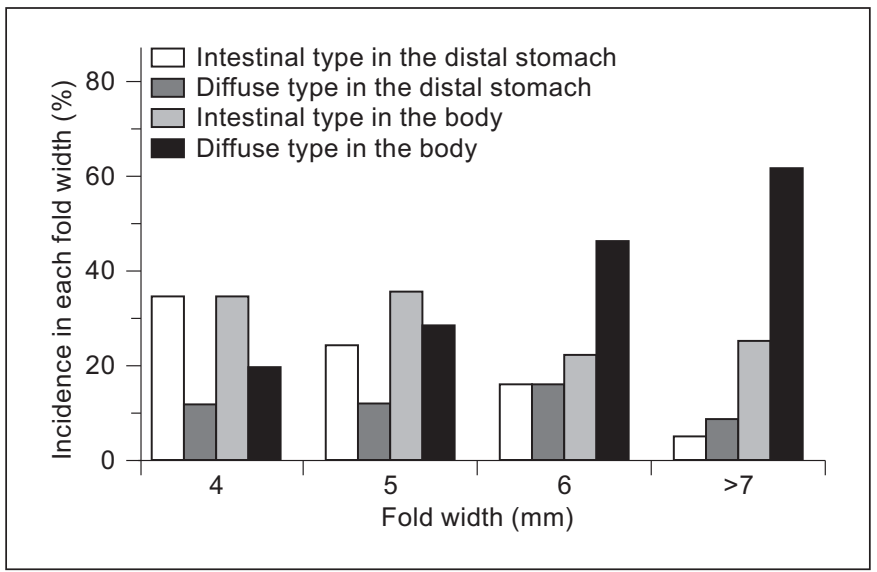

Fig. 3. Association between fold width, histological type and location of gastric cancers. The results are derived from Nishibayashi et al. [5].

\section{H. pylori-Induced Gastritis and Diffuse-Type Gastric Cancer}

In gastric cancers, epigenetic alteration of tumor-related genes reportedly occurs much more frequently than genetic alteration. The frequencies of APC, KRAS and p53 mutations, which play important roles in colorectal multistep carcinogenesis, are especially low in diffusetype gastric cancer [12]. Although CDH1 mutations are detected in approximately half of sporadic diffuse-type gastric cancers $[53,54]$, they are rarely found in early diffuse-type gastric cancers and are generally associated with the progression from differentiated to undifferentiated cancer $[7,19]$. By contrast, hypermethylation of $\mathrm{CDH} 1$ is observed in more than $50 \%$ of early diffuse-type gastric cancers $[7,12,19]$. Hypermethylation of gene promoters is strongly associated with age and chronic inflammation $[55,56]$. In the stomach, methylation of tumor-suppressor or tumor-related genes, including CDH1, increases with age $[55,57]$. In addition, a number of studies have reported the presence of gene promoter methylation in the non-neoplastic gastric mucosa of $H$. pyloriinfected individuals [58-62]. As higher methylation levels in the gastric mucosa are associated with an increased risk of gastric cancer [61-63], H. pylori infection is thought to promote stomach carcinogenesis through induction of aberrant DNA methylation.

H. pylori-related active gastritis has been divided into three groups, antrum-predominant gastritis, pangastritis and corpus-predominant gastritis. Patients with pangastritis are reportedly at high risk of diffuse-type gastric

Digestion 2011;83:241-249 
cancer [2]. It is also well known that nodularity in the gastric antrum and enlarged fold in the gastric body initiated by $H$. pylori infection are indicators of a high risk of diffuse-type gastric cancer [2, 4, 5]. Moreover, the prevalence of diffuse-type gastric cancer in the gastric body region increases with increasing fold width (fig. 3). Taken together, these findings suggest that enlarged-fold gastritis puts one at high risk of developing diffuse-type gastric cancer. Further study of aberrant DNA methylation in pangastritis, nodular gastritis, enlarged-fold gastritis and in the non-cancerous gastric mucosa of diffusetype gastric cancer patients should help to clarify the pathogenesis of diffuse-type gastric cancer and lead to identification of molecular markers to predict cancer risk.

\section{Aberrant DNA Methylation in H. pylori-Related Enlarged-Fold Gastritis}

Enlarged gastric folds are associated with a variety of diseases, including hypertrophic gastritis, Ménétrier disease, Zollinger-Ellison syndrome, primary gastrin cell hyperplasia, gastric cancer and lymphoma. The accumulated evidence suggests $H$. pylori-induced gastritis is also a possible cause of enlarged gastric folds [64-66]. $H$. $p y$ lori reportedly causes the enlarged-fold gastritis (fold width $>5 \mathrm{~mm}$ ) that accompanies foveolar hyperplasia, massive infiltration of inflammatory cells, and increased production of interleukin-1 $\beta$ (IL-1 $1 \beta$ ) and hepatocyte growth factor (HGF) in the corpus mucosa. The prevalence of enlarged-fold gastritis is higher in middle-aged (40- to 59-year-old) males than in men in other age groups or in females. It has also been reported that the prevalence of diffuse-type gastric cancer in the gastric body region increases with increasing fold width, suggesting enlarged-fold gastritis is a major risk factor for diffuse-type gastric cancer. In addition, the mutagenicity of gastric juice and mucosal levels of 8-hydroxydeoxyguanidine, an indicator of reactive oxygen species-induced DNA damage, in the body regions of the stomach in patients with enlarged-fold gastritis were significantly higher than in either $H$. pylori-negative controls or $H$. pylori-positive patients without enlarged folds [5]. Increased production of IL-1 $\beta$ and HGF, increased serum gastrin levels, and decreased acid secretion are all associated with enlargedfold gastritis and are thought to promote gastric tumorigenesis $[64,67]$.

Aberrant DNA methylation is frequently observed in enlarged-fold gastritis. $\mathrm{CDH} 1$ methylation is detected in almost all cases of $H$. pylori-induced enlarged-fold gastritis, and quantitative methylation analysis revealed that levels of CDH1 methylation are much higher in enlargedfold gastritis than in $H$. pylori-positive gastritis without enlarged folds [68, 69]. Detailed methylation analysis using bisulfite sequencing revealed that $\mathrm{CDH} 1$ is densely methylated in enlarged-fold gastritis [69], and that expression of E-cadherin is downregulated in the gastric mucosa of enlarged-fold gastritis [68]. Furthermore, a significant reduction in the level of $\mathrm{CDH} 1$ methylation is seen after $H$. pylori eradication [68]. These results strongly suggest that hypermethylation of $\mathrm{CDH} 1$ is a major contributor to the development of diffuse-type gastric cancer. It has also been reported that treatment of the MKN1 gastric cancer cell line with transforming growth factor- $\alpha$, epidermal growth factor (EGF) or reactive oxygen species induces $\mathrm{CDH} 1$ methylation, and that EGF treatment upregulated DNA methyltransferase activity [68]. Thus, inflammatory cytokines, growth factors and reactive oxygen species induced by $H$. pylori infection are likely involved in $\mathrm{CDH} 1$ methylation. This suggests CDH1 methylation could be a molecular marker predicting the development of diffuse-type gastric cancer risk.

More than $40 \%$ of the human genome is composed of repetitive sequences, including long interspersed nuclear element (LINE) and short interspersed nuclear element, and the methylation level of the former has been used as a surrogate for global methylation levels [70]. LINE-1 hypomethylation is known to occur during the development of various human malignancies, and it is reportedly associated with tumor malignancy and a poor prognosis [71-75]. One recent study revealed that levels of LINE-1 methylation are significantly reduced in the mucosa from patients with enlarged-fold gastritis [69]. The role of hypomethylation in tumorigenesis is not fully understood, but it is thought to induce activation of protooncogenes, endogenous retroviruses or transposable elements, as well as chromosomal instability. A link between LINE-1 hypomethylation and gene promoter hypermethylation (CDH1, CDH13 and PGP9.5) was also found in enlarged-fold gastritis [69]. CDH13 encodes $\mathrm{H}$-cadherin, which is involved in suppressing cell growth, invasion and metastasis, is frequently methylated in gastric cancer [76]. In addition, PGP9.5 was identified in a screening for epigenetically silenced genes in diffuse-type gastric cancer, and it has been shown to serve as a tumor suppressor in gastric cancer [77]. Thus, gene hypermethylation and global hypomethylation both appear to be forces driving the development of diffuse-type cancer in enlarged-fold gastritis (fig. 4). Further analysis of aberrant DNA meth- 


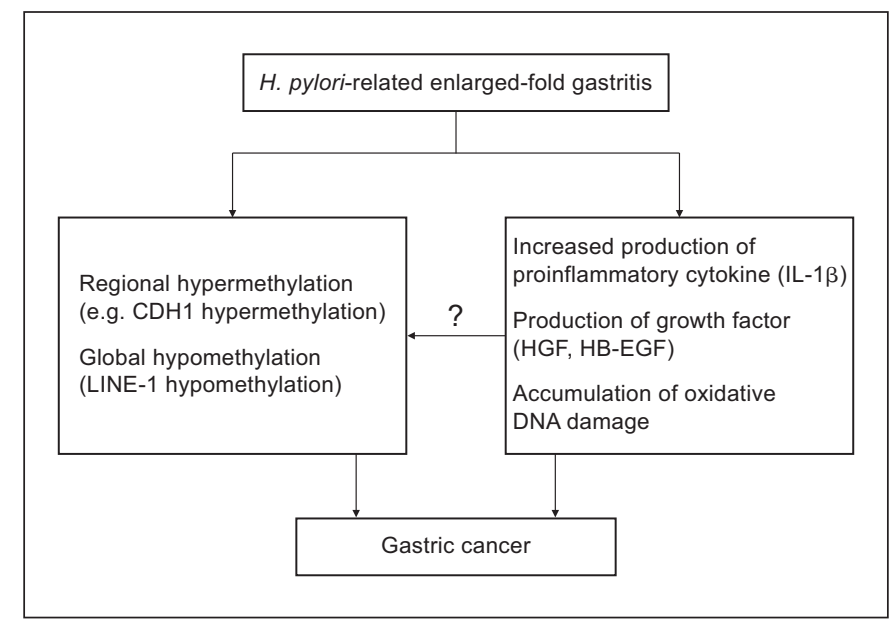

Fig. 4. Hypothesis for the progression of gastric cancer in H. pylori-induced enlarged-fold gastritis.

ylation in enlarged-fold gastritis should shed light on the molecular mechanisms underlying gastric tumorigenesis.

In patients with enlarged-fold gastritis, inflammatory infiltrates, cytokine release, foveolar thickness and fold width are all significantly reduced after eradication of $H$. pylori [66]. Eradication of $H$. pylori also restores acid secretion and decreases serum gastrin concentrations [64]. Reduction of $\mathrm{CDH} 1$ methylation after $\mathrm{H}$. pylori eradication in chronic gastritis has also been reported [78-80]. It is thus possible that eradication of $H$. pylori reduces the risk of diffuse-type gastric cancer; however, eradication does not completely restore normal DNA methylation, and individuals with sustained alteration of DNA methylation are thought to be at higher risk, even after $H$. $p y$ lori eradication. Evaluation of DNA methylation after eradication also may serve as a useful diagnostic tool for predicting cancer development, although further study is needed to clarify the relationship between residual methylation and cancer risk after eradication.

\section{Prospects}

From the available evidence, it is clear that both genetic and epigenetic alterations play an important role in the development of diffuse-type gastric cancer. H. pylori infection induces aberrant DNA methylation of multiple genes, including $\mathrm{CDH} 1$, in gastric mucosa and enlargedfold gastritis, which puts the patient at high risk for diffuse-type gastric cancer. In addition, global hypomethylation is also commonly observed in enlarged-fold gastritis. Further study of DNA methylation in high-risk individuals should not only clarify the mechanism underlying gastric carcinogenesis, but may also lead to the development of new molecular markers for risk prediction and early detection of gastric cancer.

\section{Acknowledgement}

We thank Dr. W.F. Goldman for editing the manuscript.

\section{References}

1 Jemal A, Siegel R, Ward E, Murray T, Xu J, Thun MJ: Cancer statistics, 2007. CA Cancer J Clin 2007;57:43-66.

-2 Uemura N, Okamoto S, Yamamoto S, Matsumura N, Yamaguchi S, Yamakido M, Taniyama K, Sasaki N, Schlemper RJ: Helicobacter pylori infection and the development of gastric cancer. N Engl J Med 2001:345: 784-789.

3 Yuasa Y: Control of gut differentiation and intestinal-type gastric carcinogenesis. Nat Rev Cancer 2003;3:592-600.

4 Komoto K, Haruma K, Kamada T, Tanaka S, Yoshihara M, Sumii K, Kajiyama G, Talley NJ: Helicobacter pylori infection and gastric neoplasia: correlations with histological gastritis and tumor histology. Am J Gastroenterol 1998;93:1271-1276.

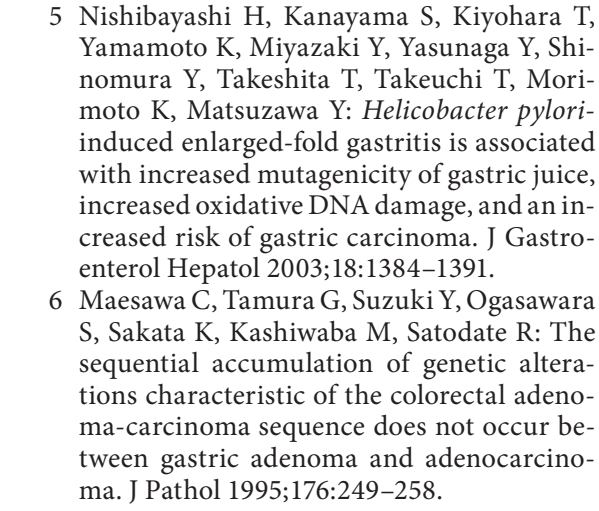

-7 Tamura G, Sato K, Akiyama S, Tsuchiya T, Endoh Y, Usuba O, Kimura W, Nishizuka S, Motoyama T: Molecular characterization of undifferentiated-type gastric carcinoma. Lab Invest 2001;81:593-598.

-8 Tamura G, Sakata K, Nishizuka S, Maesawa C, Suzuki Y, Iwaya T, Terashima M, Saito K, Satodate R: Inactivation of the E-cadherin gene in primary gastric carcinomas and gastric carcinoma cell lines. Jpn J Cancer Res 1996;87:1153-1159.

-9 Guilford P, Hopkins J, Harraway J, McLeod M, McLeod N, Harawira P, Taite H, Scoular $\mathrm{R}$, Miller A, Reeve AE: E-cadherin germline mutations in familial gastric cancer. Nature 1998;392:402-405. 
10 Lee JH, Abraham SC, Kim HS, Nam JH, Choi C, Lee MC, Park CS, Juhng SW, Rashid A, Hamilton SR, Wu TT: Inverse relationship between APC gene mutation in gastric adenomas and development of adenocarcinoma. Am J Pathol 2002;161:611-618.

-11 Park WS, Oh RR, Park JY, Lee SH, Shin MS, Kim YS, Kim SY, Lee HK, Kim PJ, Oh ST, Yoo NJ, Lee JY: Frequent somatic mutations of the $\beta$-catenin gene in intestinal-type gastric cancer. Cancer Res 1999;59:4257-4260.

12 Ushijima T, Sasako M: Focus on gastric cancer. Cancer Cell 2004;5:121-125.

13 Jones PA, Baylin SB: The epigenomics of cancer. Cell 2007;128:683-692.

14 Toyota M, Issa JP: Epigenetic changes in solid and hematopoietic tumors. Semin Oncol 2005;32:521-530.

15 Ushijima T, Okochi-Takada E: Aberrant methylations in cancer cells: where do they come from? Cancer Sci 2005;96:206-211.

16 Suzuki H, Tokino T, Shinomura Y, Imai K, Toyota M: DNA methylation and cancer pathways in gastrointestinal tumors. Pharmacogenomics 2008;9:1917-1928.

-17 Suzuki H, Itoh F, Toyota M, Kikuchi T, Kakiuchi $\mathrm{H}$, Hinoda Y, Imai K: Distinct methylation pattern and microsatellite instability in sporadic gastric cancer. Int J Cancer 1999;83: 309-313.

18 Ohmura K, Tamura G, Endoh Y, Sakata K, Takahashi T, Motoyama T: Microsatellite alterations in differentiated-type adenocarcinomas and precancerous lesions of the stomach with special reference to cellular phenotype. Hum Pathol 2000;31:1031-1035.

19 Tamura G: Alterations of tumor suppressor and tumor-related genes in the development and progression of gastric cancer. World J Gastroenterol 2006;12:192-198.

-20 Kang GH, Shim YH, Jung HY, Kim WH, Ro JY, Rhyu MG: CpG island methylation in premalignant stages of gastric carcinoma. Cancer Res 2001;61:2847-2851.

21 Waki T, Tamura G, Tsuchiya T, Sato K, Nishizuka S, Motoyama T: Promoter methylation status of E-cadherin, hMLH1, and p16 genes in non-neoplastic gastric epithelia. Am J Pathol 2002;161:399-403.

-22 To KF, Leung WK, Lee TL, Yu J, Tong JH, Chan MW, Ng EK, Chung SC, Sung JJ: Promoter hypermethylation of tumor-related genes in gastric intestinal metaplasia of patients with and without gastric cancer. Int J Cancer 2002;102:623-628.

-23 Kang GH, Lee HJ, Hwang KS, Lee S, Kim JH, Kim JS: Aberrant CpG island hypermethylation of chronic gastritis, in relation to aging, gender, intestinal metaplasia, and chronic inflammation. Am J Pathol 2003;163:15511556.

24 Nojima M, Suzuki H, Toyota M, Watanabe Y, Maruyama R, Sasaki S, Sasaki Y, Mita H, Nishikawa N, Yamaguchi K, Hirata K, Itoh F, Tokino T, Mori M, Imai K, Shinomura Y: Frequent epigenetic inactivation of SFRP genes and constitutive activation of Wnt signaling in gastric cancer. Oncogene 2007;26: 4699-4713.
25 Sato $H$, Suzuki H, Toyota M, Nojima M, Maruyama R, Sasaki S, Takagi H, Sogabe Y, Sasaki Y, Idogawa M, Sonoda T, Mori M, Imai K, Tokino T, Shinomura Y: Frequent epigenetic inactivation of Dickkopf family genes in human gastrointestinal tumors. Carcinogenesis 2007;28:2459-2466.

26 Taniguchi H, Yamamoto H, Hirata T, Miyamoto N, Oki M, Nosho K, Adachi Y, Endo T, Imai K, Shinomura Y: Frequent epigenetic inactivation of Wnt inhibitory factor-1 in human gastrointestinal cancers. Oncogene 2005;24:7946-7952.

27 Maruyama R, Akino K, Toyota M, Suzuki H, Imai T, Ohe-Toyota M, Yamamoto E, Nojima M, Fujikane T, Sasaki Y, Yamashita T, Watanabe Y, Hiratsuka H, Hirata K, Itoh F, Imai K, Shinomura Y, Tokino T: Cytoplasmic RASSF2A is a proapoptotic mediator whose expression is epigenetically silenced in gastric cancer. Carcinogenesis 2008;29:13121318.

28 Toyota M, Ahuja N, Ohe-Toyota M, Herman JG, Baylin SB, Issa JP: CpG island methylator phenotype in colorectal cancer. Proc Natl Acad Sci USA 1999;96:8681-8686.

29 Kusano M, Toyota M, Suzuki H, Akino K, Aoki F, Fujita M, Hosokawa M, Shinomura Y, Imai K, Tokino T: Genetic, epigenetic, and clinicopathologic features of gastric carcinomas with the CpG island methylator phenotype and an association with Epstein-Barr virus. Cancer 2006;106:1467-1479.

30 Caldas C, Carneiro F, Lynch HT, Yokota J, Wiesner GL, Powell SM, Lewis FR, Huntsman DG, Pharoah PD, Jankowski JA, MacLeod P, Vogelsang H, Keller G, Park KG, Richards FM, Maher ER, Gayther SA, Oliveira C, Grehan N, Wight D, Seruca R, Roviello F, Ponder BA, Jackson CE: Familial gastric cancer: overview and guidelines for management. J Med Genet 1999;36:873-880.

-31 Pedrazzani C, Corso G, Marrelli D, Roviello F: E-cadherin and hereditary diffuse gastric cancer. Surgery 2007;142:645-657.

32 Cisco RM, Ford JM, Norton JA: Hereditary diffuse gastric cancer: implications of genetic testing for screening and prophylactic surgery. Cancer 2008;113(suppl):1850-1856.

33 Pharoah PD, Guilford P, Caldas C: International Gastric Cancer Linkage Consortium. Incidence of gastric cancer and breast cancer in $\mathrm{CDH} 1$ (E-cadherin) mutation carriers from hereditary diffuse gastric cancer families. Gastroenterology 2001;121:1348-1353.

34 Jeanes A, Gottardi CJ, Yap AS: Cadherins and cancer: how does cadherin dysfunction promote tumor progression? Oncogene 2008;27:6920-6929.

35 Carneiro F, Oliveira C, Suriano G, Seruca R: Molecular pathology of familial gastric cancer, with an emphasis on hereditary diffuse gastric cancer. J Clin Pathol 2008;61:25-30.

36 Takai D, Jones PA: Comprehensive analysis of $\mathrm{CpG}$ islands in human chromosomes 21 and 22. Proc Natl Acad Sci USA 2002;99: 3740-3745.
37 Grady WM, Willis J, Guilford PJ, Dunbier AK, Toro TT, Lynch H, Wiesner G, Ferguson K, Eng C, Park JG, Kim SJ, Markowitz S: Methylation of the $\mathrm{CDH} 1$ promoter as the second genetic hit in hereditary diffuse gastric cancer. Nat Genet 2000;26:16-17.

- 38 Oliveira C, Sousa S, Pinheiro H, Karam R, Bordeira-Carriço R, Senz J, Kaurah P, Carvalho J, Pereira R, Gusmão L, Wen X, Cipriano MA, Yokota J, Carneiro F, Huntsman D, Seruca R: Quantification of epigenetic and genetic second hits in $\mathrm{CDH} 1$ during hereditary diffuse gastric cancer syndrome progression. Gastroenterology 2009;136:21372148 .

-39 Muretto P, Ruzzo A, Pizzagalli F, Graziano F, Maltese P, Zingaretti C, Berselli E, Donnarumma N, Magnani M: Endogastric capsule for E-cadherin gene $(\mathrm{CDH} 1)$ promoter hypermethylation assessment in DNA from gastric juice of diffuse gastric cancer patients. Ann Oncol 2008;19:516-519.

40 Thompson MP, Kurzrock R: Epstein-Barr virus and cancer. Clin Cancer Res 2004; 10: 803-821.

41 Fukayama M, Hino R, Uozaki H: EpsteinBarr virus and gastric carcinoma: virus-host interactions leading to carcinoma. Cancer Sci 2008;99:1726-1733

42 Akiba S, Koriyama C, Herrera-Goepfert R, Eizuru Y: Epstein-Barr virus associated gastric carcinoma: epidemiological and clinicopathological features. Cancer Sci 2008;99: 195-201.

43 Uozaki H, Fukayama M: Epstein-Barr virus and gastric carcinoma - viral carcinogenesis through epigenetic mechanisms. Int J Clin Exp Pathol 2008;1:198-216.

44 Burke AP, Yen TS, Shekitka KM, Sobin LH: Lymphoepithelial carcinoma of the stomach with Epstein-Barr virus demonstrated by polymerase chain reaction. Mod Pathol 1990;3:377-380.

45 Chong JM, Sakuma K, Sudo M, Ushiku T, Uozaki H, Shibahara J, Nagai H, Funata N, Taniguchi $\mathrm{H}$, Aburatani H, Fukayama M: Global and non-random CpG-island methylation in gastric carcinoma associated with Epstein-Barr virus. Cancer Sci 2003;94:7680.

46 Kang GH, Lee S, Kim WH, Lee HW, Kim JC, Rhyu MG, Ro JY: Epstein-Barr virus-positive gastric carcinoma demonstrates frequent aberrant methylation of multiple genes and constitutes $\mathrm{CpG}$ island methylator phenotype-positive gastric carcinoma. Am J Pathol 2002;160:787-794.

47 Chang MS, Uozaki H, Chong JM, Ushiku T, Sakuma K, Ishikawa S, Hino R, Barua RR, Iwasaki Y, Arai K, Fujii H, Nagai H, Fukayama M: CpG island methylation status in gastric carcinoma with and without infection of Epstein-Barr virus. Clin Cancer Res 2006;12: 2995-3002.

48 Kang GH, Lee S, Cho NY, Gandamihardja T, Long TI, Weisenberger DJ, Campan M, Laird PW: DNA methylation profiles of gastric carcinoma characterized by quantitative DNA methylation analysis. Lab Invest 2008;88: 161-170. 
-49 Toyota M, Ahuja N, Suzuki H, Itoh F, OheToyota M, Imai K, Baylin SB, Issa JP: Aberrant methylation in gastric cancer associated with the $\mathrm{CpG}$ island methylator phenotype. Cancer Res 1999;59:5438-5442.

-50 Fukayama M, Hayashi Y, Iwasaki Y, Chong J, Ooba T, Takizawa T, Koike M, Mizutani S, Miyaki M, Hirai K: Epstein-Barr virus-associated gastric carcinoma and Epstein-Barr virus infection of the stomach. Lab Invest 1994;71:73-81.

51 Oda K, Koda K, Takiguchi N, Nunomura M, Seike K, Miyazaki M: Detection of EpsteinBarr virus in gastric carcinoma cells and surrounding lymphocytes. Gastric Cancer 2003;6:173-178.

52 Ushiku T, Chong JM, Uozaki H, Hino R, Chang MS, Sudo M, Rani BR, Sakuma K, Nagai H, Fukayama M: p73 gene promoter methylation in Epstein-Barr virus-associated gastric carcinoma. Int J Cancer 2007;120: 60-66.

-53 Muta H, Noguchi M, Kanai Y, Ochiai A, Nawata H, Hirohashi S: E-cadherin gene mutations in signet ring cell carcinoma of the stomach. Jpn J Cancer Res 1996;87:843848 .

54 Chen TW, Hsu HM: Mechanisms inactivating the gene for E-cadherin in sporadic gastric carcinomas. World J Gastroenterol 2006; 12:2168-2173.

-55 Waki T, Tamura G, Sato M, Motoyama T: Age-related methylation of tumor suppressor and tumor-related genes: an analysis of autopsy samples. Oncogene 2003;22:41284133.

56 Niwa T, Tsukamoto T, Toyoda T, Mori A, Tanaka H, Maekita T, Ichinose M, Tatematsu M, Ushijima T: Inflammatory processes triggered by Helicobacter pylori infection cause aberrant DNA methylation in gastric epithelial cells. Cancer Res 2010;70:1430-1440.

- 57 So K, Tamura G, Honda T, Homma N, Waki T, Togawa N, Nishizuka S, Motoyama T: Multiple tumor suppressor genes are increasingly methylated with age in non-neoplastic gastric epithelia. Cancer Sci 2006;97: 1155-1158.

58 Chan AO, Lam SK, Wong BC, Wong WM, Yuen MF, Yeung YH, Hui WM, Rashid A, Kwong YL: Promoter methylation of E-cadherin gene in gastric mucosa associated with Helicobacter pylori infection and in gastric cancer. Gut 2003;52:502-506.

-59 Maekita T, Nakazawa K, Mihara M, Nakajima T, Yanaoka K, Iguchi M, Arii K, Kaneda A, Tsukamoto T, Tatematsu M, Tamura G, Saito D, Sugimura T, Ichinose M, Ushijima T: High levels of aberrant DNA methylation in Helicobacter pylori-infected gastric mucosae and its possible association with gastric cancer risk. Clin Cancer Res 2006;12:989995.
60 Ushijima T, Nakajima T, Maekita T: DNA methylation as a marker for the past and future. J Gastroenterol 2006;41:401-407.

-61 Kaise M, Yamasaki T, Yonezawa J, Miwa J, Ohta Y, Tajiri H: CpG island hypermethylation of tumor-suppressor genes in $H$. pyloriinfected non-neoplastic gastric mucosa is linked with gastric cancer risk. Helicobacter 2008;13:35-41.

62 Tahara T, Arisawa T, Shibata T, Wang FY, Nakamura M, Sakata M, Nagasaka M, Takagi T, Kamiya Y, Fujita H, Nakamura M Hasegawa S, Iwata M, Takahama K, Watanabe M, Hirata I, Nakano H: Risk prediction of gastric cancer by analysis of aberrant DNA methylation in non-neoplastic gastric epithelium. Digestion 2007;75:54-61.

63 Nakajima T, Maekita T, Oda I, Gotoda T, Yamamoto S, Umemura S, Ichinose M, Sugimura T, Ushijima T, Saito D: Higher methylation levels in gastric mucosae significantly correlate with higher risk of gastric cancers. Cancer Epidemiol Biomarkers Prev 2006;15:2317-2321.

64 Yasunaga Y, Shinomura Y, Kanayama S, Yabu M, Nakanishi T, Miyazaki Y, Murayama Y, Bonilla-Palacios JJ, Matsuzawa Y: Improved fold width and increased acid secretion after eradication of the organism in Helicobacter pylori associated enlarged fold gastritis. Gut 1994;35:1571-1574.

65 Stolte M, Bätz CH, Bayerdörffer E, Eidt S: He licobacter pylori eradication in the treatment and differential diagnosis of giant folds in the corpus and fundus of the stomach. Z Gas troenterol 1995;33:198-201.

66 Yasunaga Y, Shinomura Y, Kanayama S, Higashimoto Y, Yabu M, Miyazaki Y, Kondo S, Murayama Y, Nishibayashi H, Kitamura S, Matsuzawa Y: Increased production of interleukin 1 beta and hepatocyte growth factor may contribute to foveolar hyperplasia in enlarged fold gastritis. Gut 1996;39:787-794.

67 Murayama Y, Miyagawa J, Shinomura Y, Kanayama S, Yasunaga Y, Nishibayashi H, Yamamori K, Higashimoto Y, Matsuzawa Y Morphological and functional restoration of parietal cells in Helicobacter pylori associated enlarged fold gastritis after eradication. Gut 1999;45:653-661.

68 Miyazaki T, Murayama Y, Shinomura Y, Yamamoto T, Watabe K, Tsutsui S, Kiyohara $\mathrm{T}$, Tamura S, Hayashi N: E-cadherin gene promoter hypermethylation in $H$. pylori-induced enlarged fold gastritis. Helicobacter 2007;12:523-531.

69 Yamamoto E, Toyota M, Suzuki H, Kondo Y, Sanomura T, Murayama Y, Ohe-Toyota M, Maruyama R, Nojima M, Ashida M, Fujii K, Sasaki Y, Hayashi N, Mori M, Imai K, Tokino T, Shinomura Y: LINE-1 hypomethylation is associated with increased CpG island methylation in Helicobacter pylori-related enlarged-fold gastritis. Cancer Epidemiol Biomarkers Prev 2008;17:2555-2564.
70 Yang AS, Estécio MR, Doshi K, Kondo Y, Tajara EH, Issa JP: A simple method for estimating global DNA methylation using bisulfite PCR of repetitive DNA elements. Nucleic Acids Res 2004;32:e38.

71 Takai D, Yagi Y, Habib N, Sugimura T, Ushijima T: Hypomethylation of LINE1 retrotransposon in human hepatocellular carcinomas, but not in surrounding liver cirrhosis. Jpn J Clin Oncol 2000;30:306-309.

72 Chalitchagorn K, Shuangshoti S, Hourpai $\mathrm{N}$, Kongruttanachok N, Tangkijvanich $\mathrm{P}$, Thong-ngam D, Voravud N, Sriuranpong V, Mutirangura A: Distinctive pattern of LINE1 methylation level in normal tissues and the association with carcinogenesis. Oncogene 2004;23:8841-8846.

73 Estécio MR, Gharibyan V, Shen L, Ibrahim AE, Doshi K, He R, Jelinek J, Yang AS, Yan PS, Huang TH, Tajara EH, Issa JP: LINE-1 hypomethylation in cancer is highly variable and inversely correlated with microsatellite instability. PLoS One 2007;2:e399.

-74 Ogino S, Kawasaki T, Nosho K, Ohnishi M, Suemoto Y, Kirkner GJ, Fuchs CS: LINE-1 hypomethylation is inversely associated with microsatellite instability and $\mathrm{CpG}$ island methylator phenotype in colorectal cancer. Int J Cancer 2008;122:2767-2773.

$>75$ Lee HS, Kim BH, Cho NY, Yoo EJ, Choi M, Shin SH, Jang JJ, Suh KS, Kim YS, Kang GH: Prognostic implications of and relationship between $\mathrm{CpG}$ island hypermethylation and repetitive DNA hypomethylation in hepatocellular carcinoma. Clin Cancer Res 2009; 15:812-820.

76 Hibi K, Kodera Y, Ito K, Akiyama S, Nakao A: Methylation pattern of CDH13 gene in digestive tract cancers. Br J Cancer 2004;91: 1139-1142.

77 Yamashita K, Park HL, Kim MS, Osada M, Tokumaru Y, Inoue H, Mori M, Sidransky D: PGP9.5 methylation in diffuse-type gastric cancer. Cancer Res 2006;66:3921-3927.

78 Chan AO, Peng JZ, Lam SK, Lai KC, Yuen MF, Cheung HK, Kwong YL, Rashid A, Chan CK, Wong BC: Eradication of Helicobacter pylori infection reverses E-cadherin promoter hypermethylation. Gut 2006;55:463-468.

79 Leung WK, Man EP, Yu J, Go MY, To KF, Yamaoka Y, Cheng VY, Ng EK, Sung JJ: Effects of Helicobacter pylori eradication on methylation status of E-cadherin gene in non-cancerous stomach. Clin Cancer Res 2006;12:3216-3221.

>80 Perri F, Cotugno R, Piepoli A, Merla A, Quitadamo M, Gentile A, Pilotto A, Annese V, Andriulli A: Aberrant DNA methylation in non-neoplastic gastric mucosa of $H$. pyloriinfected patients and effect of eradication. Am J Gastroenterol 2007;102:1361-1371. 